\title{
Arsenic Mobility in the Ambient Sulfidic Environment: Sorption of Arsenic(V) and
}

\section{Arsenic(III) onto Disordered Mackinawite}

\author{
Mariëtte Wolthers ${ }^{1}{ }^{*}$, Laurent Charlet $^{2}$, Cornelis H. van der Weijden ${ }^{1}$, Peter R. van \\ der Linde ${ }^{3}$, and David Rickard ${ }^{4}$
}

${ }^{1}$ Department of Earth Sciences - Geochemistry, Faculty of Geosciences, Utrecht University, Utrecht, The Netherlands.

${ }^{2}$ L.G.I.T., University of Grenoble-CNRS, Grenoble, France.

${ }^{3}$ University of Professional Education Leiden, The Netherlands.

${ }^{4}$ School of Earth, Ocean and Planetary Sciences, Cardiff University, Cardiff, Wales, U.K.

Published in Geochimica Cosmochimica Acta, 2005

*E-mail: wolthers@geo.uu.nl 


\begin{abstract}
Arsenate, As(V), sorption onto synthetic iron(II) monosulfide, disordered mackinawite (FeS), is fast. $\mathrm{As}(\mathrm{V})$ sorption decreases above the point of zero surface charge of $\mathrm{FeS}$ and follows the $\mathrm{pH}$-dependent concentration of positively charged surface species. No redox reaction is observed between the $\mathrm{As}(\mathrm{V})$ ions and the mineral surface, over the time span of the experiments. This observation shows that $\mathrm{As}(\mathrm{V})$ dominantly forms an outer-sphere complex at the surface of mackinawite. Arsenite, As(III) sorption is not strongly $\mathrm{pH}$-dependent and can be expressed by a Freundlich isotherm. Sorption is fast, although slower than of As(V). As(III) also forms an outer-sphere complex at the surface of mackinawite. In agreement with previous spectroscopic studies, complexation at low $\mathrm{As}(\mathrm{V})$ and $\mathrm{As}(\mathrm{III})$ concentration occurs preferentially at the mono-coordinated sulfide edge sites. The $\mathrm{K}_{\mathrm{d}}\left(\mathrm{L} \mathrm{g}^{-1}\right)$ values obtained from linear fits to the isotherm data are $\sim 9$ for $\mathrm{As}(\mathrm{V})$ and $\sim 2$ for $\mathrm{As}(\mathrm{III})$. Stronger sorption of $\mathrm{As}(\mathrm{V})$ than As(III) and thus a higher As(III) mobility may be reflected in natural anoxic sulfidic waters when disordered mackinawite controls arsenic mobility.
\end{abstract}




\section{INTRODUCTION}

At oxic to anoxic transitions, arsenic is released from reductively dissolving iron hydroxides into the surrounding pore water, groundwater or water body (cf. Smedley and Kinniburgh, 2002). In reducing waters with low sulfide, S(-II), concentrations, arsenic occurs in solutions predominantly as oxyanions of $\mathrm{As}(\mathrm{V})$ (Fig. 1a) or As(III) (Fig. 1b) and as oligomers such as $\mathrm{As}_{6} \mathrm{O}_{6}(\mathrm{OH})_{6}$ and $\mathrm{As}_{3} \mathrm{O}_{3}(\mathrm{OH})_{3}$, the stable As(III) oligomers (Pokrovski et al., 1996; Tossell, 1997). In the presence of high S(-II) concentrations, the dissolved thioarsenite monomers $\mathrm{AsS}(\mathrm{SH})_{2}^{-}$and $\mathrm{AsS}_{2}(\mathrm{SH})^{2-}$ and trimer $\mathrm{As}_{3} \mathrm{~S}_{4}(\mathrm{SH})_{2}^{-}$may be significant (Helz et al., 1995). While many of the trace metals form insoluble sulfides in sulfide-rich, reducing environments, arsenic is distinctive in being relatively soluble at $\mathrm{pH}$ values higher than 5.5 , making As mobile over a wide range of redox conditions. Hence, a crucial control on the mobility and immobilization of arsenic is sorption onto particulate phases (Mok and Wai, 1994). In anoxic sulfidic settings, iron(II) sulfides are ubiquitous and are likely to play such a crucial role, since the geochemical cycling of As in anoxic environments is strongly correlated to the geochemistry of iron sulfide minerals (e.g. Huerta-Diaz and Morse, 1992; Morse and Luther, 1999).

Arsenic sorption onto metal oxides has been examined intensively (e.g. Pierce and Moore, 1982; Waychunas et al., 1996; Fendorf et al., 1997; Hiemstra and Van Riemsdijk, 1999; Swedlund and Webster, 1999; Ding et al., 2000). Contrastingly, only a few studies on the sorption of arsenic onto Fe(II) sulfides have been reported (Farquhar et al., 2002; Bostick and Fendorf, 2003). Farquhar et al. (2002) investigated the mechanisms whereby As(III) and $\mathrm{As}(\mathrm{V})$ in aqueous solution ( $\mathrm{pH}$ 5.5-6.5) interact with the surfaces of, among others, crystalline mackinawite (tetragonal $\mathrm{FeS}$ ) and pyrite $\left(\mathrm{FeS}_{2}\right)$ using As K-edge XAS. At low $\mathrm{As}(\mathrm{V})$ and As(III) concentrations, they observed for both As species similar surface complex 
structures with four oxygen atoms in the first shell and As to sulfur and to iron distances typical of outer-sphere complexation. At higher As(V) and As(III) concentrations, Farquhar et al. (2002) observed the formation of different surface complexes along with poorly crystalline arsenic sulfide. Bostick and Fendorf (2003) studied reactions of As(III) with crystalline troilite (hexagonal $\mathrm{FeS}$ ) and pyrite surfaces. At low $\mathrm{pH}$ and at low As(III) concentrations, Langmuir -type isotherms were obtained, suggesting monolayer adsorption, although XAS analyses indicated surface precipitates at all arsenic concentrations. Their XAS data showed a reduction of $\mathrm{As}(\mathrm{III})$ at the surface of both $\mathrm{Fe}(\mathrm{II})$ sulfides, and a structural environment similar to As in arsenopyrite (FeAsS). Although the dominant aqueous As(III) in their experiments (pH 3-11) was either the neutral $\mathrm{H}_{3} \mathrm{AsO}_{3}{ }^{0}$ or the oxyanion $\mathrm{H}_{2} \mathrm{AsO}_{3}{ }^{-}$(Fig. 1b) they observed an adsorption pH-dependence typical of cation sorption (e.g. Stumm, 1991): sorption increased with $\mathrm{pH}$. They explained this atypical behavior by the formation of $\mathrm{Fe}(\mathrm{OH})_{3}$ associated with FeAsS precipitation, since the formation of $\mathrm{Fe}(\mathrm{OH})_{3}$ is favored with increasing $\mathrm{pH}$.

The crystalline pyrite studied by Farquhar et al. (2002) and Bostick and Fendorf (2003) may be representative of pyrite in sedimentary environments. In contrast, the crystalline $\mathrm{Fe}(\mathrm{II})$ monosulfides they studied are not representative, with respect to their crystallinity (mackinawite and troilite) and their crystal structure (troilite), of the characteristically finegrained natural iron monosulfide. Disordered mackinawite, or FeS, is thought to be a major component of the AVS fraction of sediments (Berner, 1970; Spadini et al., 2003; Morse and Rickard, 2004). It is a precursor phase of pyrite, the most stable and ubiquitous authigenic iron(II) sulfide phase. Scavenging of trace elements by FeS is an important pathway for removal of these elements from solution in anoxic environments (Kornicker, 1988; Morse and Arakaki, 1993; Arakaki and Morse, 1993; Morse and Luther, 1999; Wharton et al., 2000). 
In this paper, experimentally determined sorption behavior of $\mathrm{As}(\mathrm{V})$ and $\mathrm{As}(\mathrm{III})$ onto the surface of FeS is reported. Synthetic FeS, which was characterized by Wolthers et al. (2003b; accepted), was used as a model solid for studying the interaction between aqueous arsenic species and FeS. The pH-dependence of sorption and the sorption isotherms of $\mathrm{As}(\mathrm{V})$ and As(III) were measured, and the isotherms were described by the Freundlich equation (e.g., Stumm, 1991). The results are interpreted in terms of outer-sphere surface complexation, in agreement with Farquhar et al. (2002) and with the model proposed by Wolthers et al. (accepted). Additionally, the structures of the surface complexes and the possible surface precipitates are discussed, and the sorption results are compared with the surface acid-base chemistry model proposed by Wolthers et al. (accepted).

\subsection{Disordered mackinawite properties}

Disordered mackinawite refers to the first precipitated iron(II) monosulfide phase formed through the reaction between aqueous $\mathrm{Fe}(\mathrm{II})$ or metallic iron and $\mathrm{S}(-\mathrm{II})$ under ambient conditions (cf. Rickard and Luther, 1997). It is nanocrystalline and displays a disordered tetragonal mackinawite structure (Wolthers et al., 2003b). Moreover, it was proposed that the hydrated FeS surface can be described by strongly acidic mono-coordinated and weakly acidic tri-coordinated sulfur sites as the surface reactive sites (Wolthers et al., accepted). In the latter study, the FeS solubility in the neutral pH-range is described by $K_{\mathrm{S}}^{\mathrm{app}}=\left\{\mathrm{Fe}^{2+}\right\} \cdot\left\{\mathrm{H}_{2} \mathrm{~S}(\mathrm{aq})\right\} \cdot\left\{\mathrm{H}^{+}\right\}^{-2}=10^{+4.87 \pm 0.27}$. Furthermore, they showed with acidbase titrations that the point of zero charge $\left(\mathrm{pH}_{\mathrm{PZC}}\right)$ of FeS lies at $\mathrm{pH} \sim 7.5$. The monocoordinated sulfur sites determine the acid-base properties at $\mathrm{pH}<\mathrm{pH}_{\mathrm{PZC}}$ and have a concentration of $\sim 1.2 \times 10^{-3}$ mol per gram FeS; at higher $\mathrm{pH}$ the tri-coordinated sulfur, which has a concentration of $\sim 1.2 \times 10^{-3}$ mol per gram FeS as well, determines surface charge 
changes. Total site density is 4.0 sites per $\mathrm{nm}^{2}$ (Wolthers et al., accepted). The surface complexation model proposed for FeS is summarized in Table 2.

\section{MATERIALS AND METHODS}

\subsection{Materials}

All chemicals were of analytical grade, unless otherwise stated, and used without further purification; solutions were prepared from Milli- $\mathrm{Q}^{\mathrm{TM}}$ water and purged for at least 30 minutes with $\mathrm{O}_{2}$-free $\mathrm{N}_{2}$ before use. The background ionic medium was either $0.05 \mathrm{M} \mathrm{KNO}_{3}$

(Fisher Chemicals ${ }^{\mathrm{TM}}$ ), 3-morpholinopropanesulfonic acid (MOPS, Merck ${ }^{\mathrm{TM}}$ ) or $2-$ morpholino-ethanesulfonic acid (MES, Merck ${ }^{\mathrm{TM}}$ ). Preliminary tests showed unambiguously that there was no significant influence of these media on arsenic sorption in the range of experimental conditions used. Fresh stock solutions of $\mathrm{As}(\mathrm{III})$ and $\mathrm{As}(\mathrm{V})$ were prepared, at most, five days in advance every week by dissolving $\mathrm{NaAsO}_{2}\left(\right.$ Fisher Chemicals ${ }^{\mathrm{TM}}$ ) and $\mathrm{Na}_{2} \mathrm{HAsO}_{4} \cdot 7 \mathrm{H}_{2} \mathrm{O}$ (Fisher Chemicals ${ }^{\mathrm{TM}}$ ) in Milli-Q ${ }^{\mathrm{TM}}$ water or in $0.05 \mathrm{M} \mathrm{KNO}_{3}$ and checked daily by ICP-OES or Hydride Generation AAS analysis. For all arsenic solutions the maximum initial As concentration used was at least one order of magnitude less than the solubility limit for $\mathrm{As}_{2} \mathrm{O}_{3}(\mathrm{~s})$ and $\mathrm{As}_{2} \mathrm{O}_{5}(\mathrm{~s})$. This condition was chosen to ensure that the starting As solutions were stable.

$\mathrm{S}(-\mathrm{II})$ and $\mathrm{Fe}(\mathrm{II})$ solutions were prepared before every experiment by dissolving $\mathrm{Na}_{2} \mathrm{~S} \cdot 9 \mathrm{H}_{2} \mathrm{O}$ (Fisher Chemicals $\left.{ }^{\mathrm{TM}}\right)$ or Mohr's salt $\left(\mathrm{Fe}\left(\mathrm{NH}_{4}\right)_{2}\left(\mathrm{SO}_{4}\right)_{2} \cdot 4 \mathrm{H}_{2} \mathrm{O} ; \mathrm{Merck}^{\mathrm{TM}}\right)$ in the background electrolyte. Because the salt are hydrates, the $\mathrm{Fe}$ and $\mathrm{S}$ concentrations were checked by ICP-OES analysis, where the $\mathrm{Na}$ concentration in the sulfide solution was 
assumed representative of the $\mathrm{S}$ concentration. Experiments were run under $\mathrm{O}_{2}$-free conditions by directly flushing the reaction vessel with $\mathrm{N}_{2}$ gas, which was purified by bubbling through a succession of two $15 \mathrm{wt} . \%$ pyrogallol in $50 \mathrm{wt} . \% \mathrm{KOH}$ solutions to remove $\mathrm{O}_{2}$, a Chrompack ${ }^{\mathrm{TM}}$ oxygen and sulfide scrubber for additional cleaning and Milli$\mathrm{Q}^{\mathrm{TM}}$ water to saturate the $\mathrm{N}_{2}$ with water vapor. The $\mathrm{O}_{2}$ concentration in the reaction vessels was below $1 \times 10^{-6} \mathrm{M}(0.03 \mathrm{ppm})$, which is the detection limit of the Orion ${ }^{\mathrm{TM}} \mathrm{O}_{2}$ probe $(850)$.

Fresh FeS was synthesized in situ by adding $200 \mathrm{~mL}$ of a $1 \times 10^{-3} \mathrm{M} \mathrm{S}$ (-II) solution to 200 $\mathrm{mL}$ of a $1 \times 10^{-3} \mathrm{M} \mathrm{Fe}(\mathrm{II})$ solution in the reaction vessel described in section 2.2 while constantly flushing with $\mathrm{O}_{2}$-free $\mathrm{N}_{2}$. Disordered mackinawite formed immediately and was left to age in the reaction vessel for one hour before experimentation started.

\subsection{Arsenic sorption experiments}

Sorption experiments were carried out in duplicate in a $0.05 \mathrm{M}$ ionic strength background electrolyte in four-necked round-bottom flasks. The central neck was used for $\mathrm{N}_{2}$ purging; $\mathrm{O}_{2}$-free $\mathrm{N}_{2}$ was bubbled through the solution via a Pasteur pipette inserted through a sealed ground-glass joint. The $\mathrm{N}_{2}$ outflow, via a ground glass connection in the second neck, was led through a washer bottle filled with Milli-Q ${ }^{\mathrm{TM}}$ water to prevent any $\mathrm{O}_{2}$ inflow. Purging continued for the entire duration of the experiments. The third and fourth neck were used for temperature and $\mathrm{pH}$ monitoring, solution additions and sampling. The suspensions were stirred magnetically with a Teflon ${ }^{\mathrm{TM}}$-coated stirring bar. The temperature in the reaction vessels was not controlled, but never varied more than $\pm 1.5^{\circ} \mathrm{C}$ during the course of an 
experiment. Throughout the experiments, $\mathrm{pH}$ was measured using an Orion ${ }^{\mathrm{TM}}$ Ross combined glass electrode incorporated in the reaction cell. Prior to use the electrode was calibrated in Calitech ${ }^{\mathrm{TM}} \mathrm{pH} 4,7$ and 10 buffers traceable to NIST (National Institute of Standards and Technology) standards and after use the electrode was checked for drift in the $\mathrm{pH} 7$ buffer. The drift of the electrode during a run was always less than $0.01 \mathrm{pH}$.

Experiments done in the $\mathrm{pH}$ 6-7.5 range were conducted in the 0.05 M MOPS or MES buffer solution to maintain constant $\mathrm{pH}$ conditions; experiments in the $\mathrm{pH} 7-8.5$ range were performed in a $0.05 \mathrm{M} \mathrm{KNO}_{3}$ background ionic medium. The $\mathrm{pH}$ of the MOPS and MES buffers was set with a fresh $1 \mathrm{M} \mathrm{NaOH}$ during preparation of the buffers; the $\mathrm{pH}$ of the $\mathrm{KNO}_{3}$ solution was set to the desired value by small additions of $1 \mathrm{M} \mathrm{NaOH}$ or $1 \mathrm{M} \mathrm{HCl}$ aliquots after the FeS suspension had been allowed to equilibrate for one hour. In the overlap of both $\mathrm{pH}$ ranges, no difference in experimental results was found showing no significant influence of the MOPS buffer on sorption in the range of experimental conditions used. The concentration of the in situ prepared FeS was $0.5 \times 10^{-3} \mathrm{M}$, that is $\sim 0.044 \mathrm{~g} \mathrm{~L}^{-1}$.

The individual $\mathrm{pH}$-dependence experiments were performed for periods of up to six hours; the total $\mathrm{As}(\mathrm{V})$ and $\mathrm{As}(\mathrm{III})$ concentration was $\sim 3 \times 10^{-5} \mathrm{M}$. Aliquots of the suspension were taken periodically over the course of an experiment; the first aliquot was a blank sample, taken before the arsenic addition. From these experiments the $\mathrm{pH}$-dependence of sorption was established. A stable arsenic concentration in solution was reached within ten minutes for both arsenic species. The sorption isotherms for $\mathrm{As}(\mathrm{III})$ and $\mathrm{As}(\mathrm{V})$ were measured at $\mathrm{pH}$ 7.4. All solutions, including a series of arsenic solutions covering the concentration range required, were freshly prepared before each experiment in a 0.05 M MOPS buffer solution set to $\mathrm{pH}$ 7.4. Known amounts of $\mathrm{As}(\mathrm{III})$ or $\mathrm{As}(\mathrm{V})$ were added to the FeS suspension and left for half an hour, a time sufficient for the arsenic concentration to stabilize. Aliquots were taken 
after 30 minutes, before the next arsenic addition. $\mathrm{As}(\mathrm{V})$ reduction by $\mathrm{FeS}$ was investigated by acid titrations of FeS suspensions with arsenic initially sorbed on the surface at $\mathrm{pH} \sim 7.5$. Subsequently, the $\mathrm{pH}$ was lowered to $\mathrm{pH} 6$ by slowly adding $0.1 \mathrm{M} \mathrm{HCl}$ solution aliquots, while regularly sampling the suspension.

From the total reaction volume of $400 \mathrm{~mL}$ aliquots of $5 \mathrm{~mL}$ were taken by pipette and transferred immediately into a syringe for filtration through a $0.45 \mu \mathrm{m}$ pore diameter Acrodisc $^{\mathrm{TM}}$ HT Tuffryn filter disc. Subsequently, the filter membrane was washed with 5 $\mathrm{mL} 6 \mathrm{M} \mathrm{HCl}$ to dissolve FeS. Sample preparation for analysis was done on the same day as the experiment; the samples were stored at $4^{\circ} \mathrm{C}$ and analyzed within a week.

In order to check for $\mathrm{As}(\mathrm{III})$ and $\mathrm{As}(\mathrm{V})$ sinks other than $\mathrm{FeS}$ in the set-up, control experiments were conducted without FeS present. No loss of dissolved arsenic occurred in these control runs. $\mathrm{H}_{2} \mathrm{~S}$ degassing was negligible over the course of an experiment (cf. method described by Wolthers et al., accepted). Nevertheless, during experiments at $\mathrm{pH}<7$, the $\mathrm{N}_{2}$ outflow from the reaction vessel was bubbled through a concentrated $\mathrm{Fe}(\mathrm{II})$ solution. If any $\mathrm{H}_{2} \mathrm{~S}(\mathrm{~g})$ bubbled through, the solution would turn black, but no color was observed.

\subsection{Solution analyses}

Total dissolved iron in the filtrates was measured spectrophotometrically by the ferrozine method (Viollier et al., 2000) using a Unicam ${ }^{\mathrm{TM}}$ UV1 spectrophotometer. Furthermore, samples were routinely analyzed for a range of elements including Fe and As concentrations by ICP-OES (Perkin Elmer ${ }^{\text {TM }}$ Optima 3000$)$. 
Total dissolved arsenic and dissolved As(III) concentrations were determined using a AAS5100 with a MHS-20 hydride system (Perkin Elmer ${ }^{\mathrm{TM}}$ ). In the hydride system, only dissolved $\mathrm{As}(\mathrm{III})$ is rapidly reduced to arsine, $\mathrm{AsH}_{3}$, and analyzed. In order to analyze total dissolved arsenic, sample preparation included the reduction of $\mathrm{As}(\mathrm{V})$ to $\mathrm{As}(\mathrm{III})$. Contrastingly, in the sample preparation for dissolved As(III) analyses, the reduction of $\mathrm{As}(\mathrm{V})$ to As(III) was avoided. Thus, depending on the sample preparation before hydride generation, As(III) or total arsenic was determined (Kuhn and Sigg, 1993; Isenbeck-Schröter, 2002). The concentration of $\mathrm{As}(\mathrm{V})$ was calculated from the difference between the total As and $\mathrm{As}(\mathrm{III})$ concentrations.

The selective determination of As(III) only works in the $\mathrm{pH}$ range from 4 to 6 (Kuhn and Sigg, 1993). Therefore, $10 \mathrm{~mL}$ samples were mixed with $10 \mathrm{~mL}$ of buffer solution to set the $\mathrm{pH}$ at 5 . The buffer solution consisted of 25 wt. $\%$ Citric Acid Monohydrate (Merck ${ }^{\mathrm{TM}}$ ) and 11 wt.\% $\mathrm{NaOH}$ in Milli-Q ${ }^{\mathrm{TM}}$ water (after Kuhn and Sigg, 1993). The calibration solutions were made by a step dilution of a $13.4 \times 10^{-6} \mathrm{M} \mathrm{As}(\mathrm{III})$ solution. During the hydride formation, the $\mathrm{pH}$ dropped to a minimum of $\sim 4$. The pre-reduction step of $\mathrm{As}(\mathrm{V})$ to $\mathrm{As}(\mathrm{III})$ required for total As analysis was performed in $15 \mathrm{~mL}$ centrifuge tubes $\left(\operatorname{Greiner}^{\mathrm{TM}}\right)$ : $10 \mathrm{~mL}$ of the sample solution was allowed to reacted with $3 \mathrm{~mL}$ concentrated $\mathrm{HCl}\left(\mathrm{Merck}^{\mathrm{TM}}\right)$ and 1 $\mathrm{mL}$ of the pre-reducing reagent, a $10 \mathrm{wt} . \%$ potassium iodide (Merck ${ }^{\mathrm{TM}}$, suprapur) and 10 wt.\% ascorbic acid (Merck ${ }^{\mathrm{TM}}$ ) in Milli-Q ${ }^{\mathrm{TM}}$ water (after Kuhn and Sigg, 1993). The calibration solutions were prepared through a step dilution of a $13.4 \times 10^{-6} \mathrm{M} \mathrm{As}(\mathrm{V})$ solution. The pre-reduction step was complete within one hour at room temperature. Within the MHS-20 system, the final reduction step of As(III) to arsine prior to analysis was done

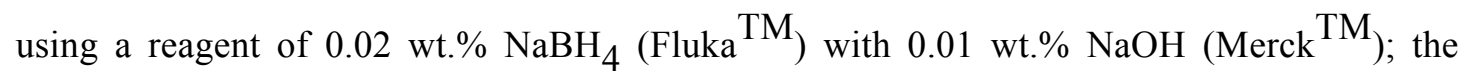
reducing reagent was stable for two days. 


\section{RESULTS}

\subsection{FeS stability}

Figure 2 shows the $\mathrm{pH}$ dependence of the total iron concentration measured in the supernatant of the $\operatorname{As}(\mathrm{V})$ experiments (Fig. 2a) and the As(III) experiments (Fig. 2b). Also shown in

Figures $2 \mathrm{a}$ and $2 \mathrm{~b}$ is the solubility of disordered mackinawite, $\log K_{\mathrm{S}}^{\mathrm{app}}=+4.87 \pm 0.27$ from Wolthers et al., (accepted). The scatter in the iron data from the sorption experiments is significantly larger than observed in the study by Wolthers et al. (accepted). Moreover, on average, the iron concentrations in the supernatant of the As(III) experiments tend to be higher than the previously observed FeS solubility, while in the As(V) experiments, the iron concentrations indicate an approximately similar solubility. The scatter in the iron concentration is, most likely, caused by the pore size of the filters used to separate the solid from the supernatant. This pore size, $0.45 \mu \mathrm{m}$, is larger than the $0.2 \mu \mathrm{m}$ diameter used by Wolthers et al. (accepted), and may allow for a less reproducible filtration due to the small particle size (cf. Wolthers et al., 2003b).

The data for sorption of $\mathrm{As}(\mathrm{V})$ and $\mathrm{As}(\mathrm{III})$ were normalized to the amount of FeS present as predicted by the solubility of disordered mackinawite. Such a correction is significant due to the high solubility of $\mathrm{FeS}$. For example in the experiments performed at $\mathrm{pH} 6$, up to $80 \%$ of the total iron may be in solution rather than in the solid.

\subsection{Sorption of $\operatorname{As}(\mathbf{V})$}

The sorption of $\mathrm{As}(\mathrm{V})$ onto disordered mackinawite is strongly dependent on $\mathrm{pH}$ (triangles, Fig. 3a). With decreasing $\mathrm{pH}$ from $\mathrm{pH} 8.5$ sorption first increases strongly, then, below $\mathrm{pH} 7$, a drop in sorption intensity is observed. The scatter in the sorption pH-dependence plot (Fig. 
3a) can be explained by the variance in specific surface area of the disordered mackinawite over a series of separate experiments (Wolthers et al., 2003b, accepted), or by the effect of the pore size of the filters used as discussed above. The data were corrected for FeS dissolution. The strongest sorption, $73 \%$ of the total $\mathrm{As}(\mathrm{V})$, is found at $\mathrm{pH} \sim 7.4$ where $0.43 \times 10^{-3} \mathrm{~mol}$ As(V) sorbed per gram FeS, or 0.044 mol As per mol suspended FeS.

The sorption isotherm for $\mathrm{As}(\mathrm{V})$, measured at $\mathrm{pH} 7.5$, is depicted as triangles in Fig. 3b. The slope of the isotherm is $\sim 1$; it can be described as a Freundlich isotherm (e.g., Stumm, 1991). Fig. 3c shows an example of a sorption rate experiment. Within ten minutes after $\mathrm{As}(\mathrm{V})$ addition, the amount of arsenic in solution has decreased and stabilized, indicating a rapid sorption reaction. $\mathrm{As}(\mathrm{V})$ sorption was found to be associated with a slight increase of $\mathrm{pH}$ and a slight decrease in total dissolved iron was observed with $\mathrm{As}(\mathrm{V})$ sorption. No increase in As(III) concentration in either the solution or the solid extract was measured, suggesting insignificant $\mathrm{As}(\mathrm{V})$ reduction.

\subsection{Sorption of As(III)}

The sorption of the neutral As(III) complex onto disordered mackinawite (diamonds in Fig. 4a) is not as strongly $\mathrm{pH}$-dependent as the sorption of anionic $\mathrm{As}(\mathrm{V})$. There is a weak sorption maximum at $\mathrm{pH} \sim 7.2$. The data were corrected for FeS dissolution during the experiments. Similarly to the As(V) data, the scatter in the sorption pH-dependence plot (Fig. 4a) can be explained by the variance in the specific surface area of the disordered mackinawite over separate experiments (Wolthers et al., 2003b), or by the effect of the pore size of the filters used as discussed above.. The strongest sorption, $\sim 23 \%$ of the total $\mathrm{As}(\mathrm{III})$, is found at $\mathrm{pH} \sim$

7.2 where $0.13 \times 10^{-3}$ mol As sorbs per gram suspended FeS, or $0.012 \mathrm{~mol} \mathrm{As(III)} \mathrm{per} \mathrm{mol}$ FeS. 
The sorption isotherm for As(III) (diamonds in Fig. 4b) at $\mathrm{pH} 7.4$ shows linear sorption. Fig. 4c shows and example of a sorption rate experiment. Within ten minutes after As(III) addition, the amount of arsenic in solution has decreased and stabilized, indicating a rapid sorption reaction. $\mathrm{As}(\mathrm{III})$ sorption was found to be associated with a slight increase of $\mathrm{pH}$. No significant change in total dissolved iron was observed with As(III) sorption, nor was an increase in $\mathrm{As}(\mathrm{V})$ concentration in the solution or the solid extract measured. 


\section{DISCUSSION}

\section{1. $\operatorname{As}(\mathrm{V})$}

\subsection{1. pH-dependence of $A s(V)$ sorption}

Within the experimental $\mathrm{pH}$ range, the dominant $\mathrm{As}(\mathrm{V})$ species are the negatively charged $\mathrm{H}_{2} \mathrm{AsO}_{4}^{-}$and $\mathrm{HAsO}_{4}^{2-}$ (Fig. 1a). Generally, sorption of anions is strongest at low $\mathrm{pH}$ and gradually decreases as $\mathrm{pH}$ increases. For $\mathrm{As}(\mathrm{V})$ sorption onto $\mathrm{FeS}$, such an increase in sorption with decreasing $\mathrm{pH}$ is observed above $\mathrm{pH}_{\mathrm{PZC}}\left(\mathrm{pH}\right.$ 7.2). However, below $\mathrm{pH}_{\mathrm{PZC}}$, a decrease in sorption with $\mathrm{pH}$ is observed and coincides with an increase in dissolved iron concentration. The solubility of FeS increases rapidly with decreasing pH (Fig. 2). The increased instability of the solid and surface may be the cause for decreased sorption, even after correction for loss of solid. Similarly, Widler and Seward (2002), who studied the sorption of the gold(I) hydrosulfide complex $\mathrm{AuHS}^{0}$ onto several iron(II) sulfides, observed a decrease in gold sorption onto crystalline mackinawite and a simultaneous increase of dissolved iron concentration due to solid dissolution at low $\mathrm{pH}$.

Farquhar et al. (2002) investigated the mechanisms whereby As(III) and As(V) in aqueous solution ( $\mathrm{pH}$ 5.5-6.5) interact with the surface of mackinawite using X-ray absorption spectroscopy (XAS). The mackinawite they used was synthesized according to the method of Lennie and Vaughan (1996) and, hence, is more crystalline than the FeS used in the present study (Wolthers et al., 2003b) and, probably, has more acidic surface functional groups which are (Wolthers et al., accepted). These differences may influence the amount and the $\mathrm{pH}$ dependence of sorption, but they are not expected to influence the mechanism and resulting 
sorption products on the surface. They observed that, at $[\mathrm{As}(\mathrm{V})]_{\text {tot }} \approx 4 \times 10^{-5} \mathrm{M}$, the complex formed by $\mathrm{As}(\mathrm{V})$ at the mackinawite surface has four oxygen atoms in the first shell at $0.170 \mathrm{~nm}$, one sulfur atom in the second shell at $0.311 \mathrm{~nm}$ and one iron atom in the third shell at $0.351 \mathrm{~nm}$ (Farquhar et al., 2002). They concluded that $\mathrm{As}(\mathrm{V})$ forms an outer-sphere complex at the surface of mackinawite, binding to one surface sulfide group. The fact that there is only one iron in the third shell suggests that the sulfide is coordinated to one iron atom. The XAS data from Farquhar et al. (2002) therefore specifically indicate that As(V) forms an outer-sphere complex with a mono-coordinated sulfur surface site, proposed by Wolthers et al. to be the major reactive surface site (accepted, see also Table 2). Since As(V) is negatively charged in the experimental $\mathrm{pH}$ range (Fig. 1a), and since outer-sphere complexation is generally involving electrostatic interactions (e.g., Stumm, 1991), it is most likely that $=\mathrm{FeSH}_{2}^{+}$is the surface reactive species where adsorption occurs (solid line in Fig. $3 a)$.

\subsubsection{Sorption isotherm for $A s(V)$}

The $\operatorname{As}(\mathrm{V})$ sorption isotherm for FeS (Fig. 3b) is linear. As can be seen in Fig. 3b, the sorption isotherm data do not level off at the $\equiv \mathrm{FeSH}_{2}^{+}$site concentration (horizontal dashed line, Fig. 3b). This shows that $\mathrm{As}(\mathrm{V})$ does not only sorb onto $\equiv \mathrm{FeSH}_{2}^{+}$site, and that sorption continues into coprecipitation, as observed by Farquhar et al. (2002) when mackinawite is exposed to higher As concentrations, that is $\log [\mathrm{As}(\mathrm{V})]_{\mathrm{aq}} \geq-2.2$.

Sorption of $\mathrm{As}(\mathrm{V})$ can be expressed as a Freundlich isotherm $\left(R^{2}=0.88\right)$, describing the relation between the $\mathrm{As}(\mathrm{V})$ concentration in $\mathrm{mmol} \mathrm{g}^{-1} \mathrm{FeS}$ at the surface, $[\mathrm{As}(\mathrm{V})]_{\mathrm{ads}}$, and in $\mu \mathrm{M}$ solution, $[\mathrm{As}(\mathrm{V})]_{\mathrm{aq}}($ Fig. 3b): 


$$
[\operatorname{As}(\mathrm{V})]_{\mathrm{ads}}=0.021[\mathrm{As}(\mathrm{V})]_{\mathrm{aq}}^{0.90}
$$

The slope of 0.90 implies that sorption is not controlled by a single binding site (e.g. Stumm, 1991), but the scatter of points at low $\mathrm{As}(\mathrm{V})$ concentration precludes the analysis and quantification of adsorption onto high energy sites.

\subsubsection{As $(V)$ sorption characteristics}

$\mathrm{As}(\mathrm{V})$ sorption onto $\mathrm{FeS}$ is found to be fast. Within ten minutes after $\mathrm{As}(\mathrm{V})$ addition, the amount of arsenic in solution has decreased and is stable for up to at least five hours (Fig. 3c). Therefore, it may be assumed that the time used (30 minutes) between two successive As(V) additions in the sorption isotherm experiments was enough to reach "equilibrium" time. The relatively fast sorption found in this study agrees with outer-sphere complexation, which is generally a matter of minutes (e.g. Stumm, 1991). No kinetics for As(V) sorption onto iron(II) sulfides has been reported in literature. Sorption of gold(I) hydrosulfide complexes onto crystalline mackinawite has been reported to reach equilibrium within half an hour (Widler and Seward, 2002). Morse and Arakaki (1993) reported equilibration times of five to ten minutes for cobalt and nickel sorption onto FeS. For manganese sorption onto FeS, they observed equilibration times of less than thirty minutes (Arakaki and Morse, 1993). So, generally, sorption reactions with iron(II) monosulfide surfaces attain equilibrium, or at least steady state, relatively fast.

$\mathrm{As}(\mathrm{V})$ sorbs onto FeS relatively stronger than As(III) (Fig. 3a and 4a). If fitted as a linear isotherm, $\mathrm{As}(\mathrm{V})$ is found to be adsorbed with a partition coefficient, $\mathrm{K}_{\mathrm{d}}$, = $\left([\mathrm{As}(\mathrm{V})]_{\mathrm{ads}}\right)\left([\mathrm{As}(\mathrm{V})]_{\mathrm{aq}}\right)^{-1} \approx 9 \mathrm{~L} \mathrm{~g}^{-1}$. For comparison, the $\mathrm{K}_{\mathrm{d}}$ value observed for As(III) was equal to $\sim 2 \mathrm{~L} \mathrm{~g}^{-1}$, reflecting a less strong partitioning with FeS. No significant reduction of $\operatorname{As}(\mathrm{V})$ to $\mathrm{As}(\mathrm{III})$ was observed; and this confirms an outer-sphere mechanism. This is also in agreement with Farquhar et al. (2002) who observed in their XAS study that As(V) did not 
change redox state upon sorption onto the mackinawite surface. Rochette et al. (2000) found $\mathrm{As}(\mathrm{V})$ reduction by aqueous $\mathrm{S}(-\mathrm{II})$ to be insignificant at $\mathrm{pH} 7$ over a time of 7 days and the rate to increase rapidly with decreasing $\mathrm{pH}$. Bostick and Fendorf (2003) reported As(III) reduction within 15 to 30 minutes at $\mathrm{pH} \mathrm{7,} \mathrm{during} \mathrm{or} \mathrm{upon} \mathrm{sorption} \mathrm{onto} \mathrm{the} \mathrm{Fe}$ (II) sulfides troilite and pyrite. Expectedly, As(V) would also be reduced in troilite and pyrite suspensions. The absence of $\mathrm{As}(\mathrm{V})$ reduction in the sorption experiments with $\mathrm{FeS}$ is in agreement with the results of Rochette et al. (2000) and shows that the surface of FeS does not reduce $\mathrm{As}(\mathrm{V})$ within the timeframe of the experiments, which is, in turn, an additional argument in favor of an outer-sphere complex formation .

Farquhar et al. (2002) studied the complex formed by $\mathrm{As}(\mathrm{V})$ at the mackinawite surface (see section 4.1.1.). They interpreted their data as outer-sphere complexation distances, and the results presented here are generally in agreement with Farquhar et al.'s structural data. Therefore, their XAS data are used here to investigate the structural aspects of As(V) sorption onto FeS through an outer-sphere complex formation.

The As(V) oxyanion sorbs to the mono-coordinated sulfur surface site with an As-S distance of $0.311 \mathrm{~nm}$ (Farquhar et al., 2002). As the mono-coordinated sulfur surface site is positioned at the edges of the tetragonal layers only (Wolthers et al., accepted), sorption will occur preferentially at the edges of the mackinawite lattice and not at the basal (001) plane. One oxygen bridges the As and $\mathrm{S}$, the other three hydroxyl groups of the oxyanion are pointing towards the solution. The As-As distance of $0.335 \mathrm{~nm}$ observed by Farquhar et al. (2002) at the highest $\mathrm{As}(\mathrm{V})$ concentration i.e. at $\log [\mathrm{As}(\mathrm{V})]_{\mathrm{aq}} \approx-1.3$, could be explained as such a surface-complex polymerization, since it is approximately twice the length of the As-O distance. Equilibrium calculations using MINEQL+ and the data listed in Table 1, showed that, even at the highest aqueous $\mathrm{As}(\mathrm{V})$ concentrations, the solution was strongly undersaturated with respect to $\mathrm{As}_{2} \mathrm{O}_{5}$. Hence, no $\mathrm{As}(\mathrm{V})$ oxide precipitation is to be expected. 
The observed slight decrease in total dissolved iron observed with $\mathrm{As}(\mathrm{V})$ sorption suggests the (co)precipitation of a ferrous-iron containing arsenate phase. This could be similar to the $\mathrm{MnHAsO}_{4}$ phase Krautite formed at the surface of $\mathrm{MnO}_{2}$ (s) (Tournassat et al., 2002), which has an As-As distance of $0.335 \mathrm{~nm}$. However, although the XAS data from Farquhar et al. (2002) are in agreement with respect to the As-As distance of Krautite, their data show that no $\mathrm{Fe}$ is present in the surface precipitate at $\log [\mathrm{As}(\mathrm{V})]_{\mathrm{aq}} \geq-2.2$. So, the available data are inconclusive with respect to which phase precipitates.

\section{2. $\operatorname{As}(\mathrm{III})$}

\subsection{1. pH-dependence of As(III) sorption}

In the experimental $\mathrm{pH}$ range, the aqueous $\mathrm{As}(\mathrm{III})$ speciation is relatively simple (Fig. 1b) compared to $\mathrm{As}(\mathrm{V})$ (Fig. 1a). The dominant aqueous $\mathrm{As}(\mathrm{III})$ species is the neutral $\mathrm{H}_{3} \mathrm{AsO}_{3}^{0}$ complex, and its sorption onto FeS is not strongly pH-dependent (Fig. 4a), relative to $\mathrm{As}(\mathrm{V})$ sorption. Note that in the experiments performed at the lowest $\mathrm{pH}$, i.e. at $\mathrm{pH}$ 5.9, approximately $10 \%$ of the solid remains at the end of the experiments and this results in an extremely strong correction for dissolution of the solid and the large scatter observed (Fig. $4 a)$.

Farquhar et al. (2002) observed in their XAS study on the sorption of As onto mackinawite that that, at $[\mathrm{As}(\mathrm{III})]_{\text {tot }} \approx 4 \times 10^{-5} \mathrm{M}$, the complex formed by As(III) at the mackinawite surface has four oxygen atoms in the first shell at $0.176 \mathrm{~nm}$, one sulfur atom in the second shell at $0.309 \mathrm{~nm}$ and one iron atom in the third shell at $0.340 \mathrm{~nm}$. They concluded that As(III) forms an outer-sphere complex at the surface of mackinawite, binding to one surface sulfide group. Their data indicate that, like for $\mathrm{As}(\mathrm{V})$, the outer-sphere complex of $\mathrm{As}(\mathrm{III})$ 
forms at the mono-coordinated surface. Since As(III) is not charged at the experimental $\mathrm{pH}$ range of the present study(Fig. 1b), no strong $\mathrm{pH}$ dependence is expected, nor observed.

\subsubsection{Sorption isotherm for As(III)}

The As(III) sorption isotherm for FeS (Fig. 4b) can be interpreted in terms of a Freundlich isotherm. It shows no surface site saturation at high As(III) concentrations, but a linear sorption with a slope of $\sim 1.25$. Any of the predicted specific surface sites (horizontal dashed line in Fig. 4b, from Wolthers et al., accepted) would be saturated before the highest levels of sorbed As(III) in the isotherm experiment were reached. At the highest As(III) concentrations, all sites are saturated while As(III) sorption does not tend to level off, indicating a continuum from sorption to coprecipitation as observed by Farquhar et al. (2002) when mackinawite is exposed to higher $\mathrm{As}(\mathrm{III})$ concentrations, that is, at $\log [\mathrm{As}(\mathrm{III})]_{\mathrm{aq}} \approx-1.3$.

The association of As(III) with FeS can be expressed in terms of a Freundlich isotherm, describing the relation between the As(III) concentration in mmol $\mathrm{g}^{-1} \mathrm{FeS}$ at the surface, $[\mathrm{As}(\mathrm{III})]_{\mathrm{ads}}$, and in $\mu \mathrm{M}$ in solution, $[\mathrm{As}(\mathrm{III})]_{\mathrm{aq}}$ :

$$
[\mathrm{As}(\mathrm{III})]_{\mathrm{ads}}=0.026[\mathrm{As}(\mathrm{III})]_{\mathrm{aq}}^{0.98}
$$

This conditional Freundlich isotherm fits the sorption isotherm data with $R^{2}=0.98$ (Fig. 4b).

\subsubsection{As(III) sorption characteristics}

At the same total As concentration, less As(III) is sorbed than As(V) (Fig. 3a and 4a), as is reflected by the partition coefficients of $\sim 2 \mathrm{~L} \mathrm{~g}^{-1}$ for As(III) and $\sim 9 \mathrm{~L} \mathrm{~g}^{-1}$ for As(V). Similar to $\mathrm{As}(\mathrm{V}), \mathrm{As}(\mathrm{III})$ is found to sorb fast onto FeS. Within fifteen minutes after As(III) addition, the amount of arsenic in solution has decreased and is stable for up to at least four hours. No longer experiments were run. It may be assumed that the time between individual As(III) 
additions in the sorption isotherm experiments, which was 30 minutes, was a sufficient "equilibration" time. The relatively fast sorption found in the present study agrees with equilibration times observed by Bostick and Fendorf (2003) of $\sim 15$ to 30 minutes for As(III) reactions with troilite and pyrite, and, more generally, with outer-sphere complexation (e.g. Stumm, 1991).

Farquhar et al. (2002) observed that the complex formed by As(III) at the mackinawite surface is almost identical to the $\operatorname{As}(\mathrm{V})$ complex, binding to one surface sulfide group as an outer-sphere complex. So, similarly to $\mathrm{As}(\mathrm{V})$, As(III) outer-sphere complexes may form preferentially at the mono-coordinated sulfur surface site. The observed the coordination of As(III) to four oxygen atoms in the first shell (Farquhar et al., 2002) could be explained by an $\mathrm{S}-\mathrm{O}$ group existing on the surface of $\mathrm{FeS}$, and the oxygen forming the bridge between the $\mathrm{S}$ and the As(III). However, this would not be in agreement with the surface chemistry model proposed by Wolthers et al. (accepted, see also Table 2). Alternatively, the As(III) complexes at the surface may be oriented in such a way, that As(III) has four oxygen atoms in its first shell: three that are bound in its complex and one oxygen from the neighboring As(III) complex.

Farquhar et al. (2002) observed at their highest $\mathrm{As}(\mathrm{III})$ concentrations, i.e. at $\log [\mathrm{As}(\mathrm{III})]_{\mathrm{aq}}>$ -3.7 , the presence of sorption complexes and of a poorly crystalline $\mathrm{As}_{2} \mathrm{~S}_{3}$ phase in the XAS spectra (note: they studied $\mathrm{As}(\mathrm{III})$ sorption at $\log [\mathrm{As}(\mathrm{III})]_{\mathrm{aq}}$ values of approximately -4.4 , -3.7, and -1.3). Such a coprecipitation could explain the high As(III) part of the Freundlich isotherm found in the present study. Since no correlation between total dissolved iron and As(III) sorption was observed (data not shown), As(III) co-precipitates in an iron-free phase. Equilibrium calculations using MINEQL+ and the data listed in Table 1 showed that, at $\log [\mathrm{As}(\mathrm{III})]_{\mathrm{aq}}>-7$, the solution was supersaturated with respect to orpiment $\left(\mathrm{As}_{2} \mathrm{~S}_{3}\right)$, but at all $[\mathrm{As}(\mathrm{III})]_{\mathrm{aq}}$ values it was undersaturated with respect to amorphous $\mathrm{As}_{2} \mathrm{~S}_{3}$. At room 
temperatures, however, the more soluble amorphous $\mathrm{As}_{2} \mathrm{~S}_{3}$ is expected to precipitate as the precursor to orpiment (Eary, 1992). So, from the available data it may be concluded that, at higher $\mathrm{As}(\mathrm{III})$ concentrations, arsenic co-precipitates as poorly crystalline $\mathrm{As}_{2} \mathrm{~S}_{3}$ at the surfaces of FeS and mackinawite, before the solution is saturated with respect to amorphous $\mathrm{As}_{2} \mathrm{~S}_{3}$. 


\section{IMPLICATIONS}

Sorption slows down the transport of a dissolved substance compared to the water flow (Appelo and Postma, 1994) and thus is a controlling factor in the mobility and immobilization of chemicals. In the case of As sorption onto FeS, its Freundlich isotherms are straightforward relations and define a linear retardation factor. $\mathrm{As}(\mathrm{V})$ partitions more strongly with $\mathrm{FeS}$ than As(III). It follows from their different sorption behavior, that $\mathrm{As}(\mathrm{V})$ and $\mathrm{As}(\mathrm{III})$ will show differential mobility and will travel through an aquifer with different velocities. This will lead to their increased separation along a flow path in a non-steady state situation. Generally, the neutral $\mathrm{H}_{3} \mathrm{AsO}_{3}$ complex is less strongly sorbed under oxic groundwater settings than $\mathrm{As}(\mathrm{V})$ species and may travel five to six times faster than $\operatorname{As}(V)$ (Gulens et al., 1979). From the present study, it can be concluded that, under anoxic sulfidic groundwater settings, a higher As(III) mobility may also be expected if disordered mackinawite controls arsenic mobility (Wolthers et al., 2003a). 
Acknowledgements. Philippe Van Cappellen (Utrecht University) is gratefully acknowledged for insightful discussions over the course of this study. Lorenzo Spadini (Grenoble University) contributed to the discussion on the structural aspects of sorption. We also thank two anonymous reviewers and the associate editor Prof. D. Vaughan for their comments, which helped to significantly improve the manuscript. This research was financially supported by the Netherlands Organization of Scientific Research (NWO/ALW grant 750.197.06 to M.W.), by the Donder's Chair grant (Utrecht University) to L.C. and by NERC grant NRE/L/S/2000/00611 to D.R. This study was conducted under the program of the Netherlands Research School of Sedimentary Geology. 


\section{REFERENCES}

Appelo C.A.J., Postma D. (1994) Geochemistry, Groundwater and Pollution. A.A. Balkema, Rotterdam.

Arakaki T., Morse J.W. (1993) Coprecipitation and adsorption of Mn(II) with mackinawite (FeS) under conditions similar to those found in anoxic sediments. Geochim. Cosmochim. Acta 57, 9-14.

Berner R.A. (1970) Sedimentary pyrite formation. Am. J. Sci. 268, 1-23.

Bostick B.C., Fendorf S. (2003) Arsenite sorption on troilite (FeS) and pyrite $\left(\mathrm{FeS}_{2}\right)$. Geochim. Cosmochim. Acta 67, 909-921.

Davison W., Philips N., Tabner B.J. (1999) Soluble iron sulfide species in natural waters: reappraisal of their stoichiometry and stability constants. Aquat. Sci. 61, 23-43.

Ding M., de Jong B.H.W.S., Roosendaal S.J., Vredenberg A. (2000) XPS studies on the electronic structure of bonding between solid and solutes: adsorption of arsenate, chromate, phosphate, $\mathrm{Pb}^{2+}$, and $\mathrm{Zn}^{2+}$ ions on amorphous black ferric oxyhydroxide. Geochim. Cosmochim. Acta 64, 1209-1219.

Eary L.E. (1992) The solubility of amorphous $\mathrm{As}_{2} \mathrm{~S}_{3}$ from 25 to $90^{\circ} \mathrm{C}$. Geochim. Cosmochim. Acta 56, 2267-2280.

Farquhar M.L., Charnock J.M., Livens F.R., Vaughan D.J. (2002) Mechanisms of arsenic uptake from aqueous solution by interaction with goethite, lepidocrocite, mackinawite, and pyrite: an X-ray absorption spectroscopy study. Envir. Sci. Technol. 36, 1757-1762.

Fendorf S., Eick M.J., Grossl P., Sparks D.L. (1997) Arsenate and chromate retention mechanism on goethite. 1. Surface structure. Envir. Sci. Technol. 31, 315-320.

Gulens J., Champs D.R., Jackson R.E. (1979) Influence of redox environments on the mobility of arsenic in groundwater. In: Chemical Modelling of Aqueous systems (ed. E.A. Jenne ), A.C.S., pp 81-95. 
Helz G.R., Tossell J.A., Charnock J.M., Pattrick R.A.D., Vaughan D.J., Garner C.D. (1995) Oligomerization in arsenic(III) sulfide solutions: theoretical constraints and spectroscopic evidence. Geochim. Cosmochim. Acta 59, 4591-4604.

Hiemstra T., Van Riemsdijk W.H. (1999) Surface structural ion adsorption modeling of competitive binding of oxyanions by metal (hydr)oxides. J. Colloid Interf. Sci. 210, $182-193$.

Huerta-Diaz M.A., Morse J.W. (1992) Pyritization of trace metals in anoxic marine sediments. Geochim. Cosmochim. Acta 56, 2681-2702.

Isenbeck-Schröter M., Höhn R., Stadler S., Jann S., Davis J., Kent D., Niedan V., Scholz C., Tretner A., Jakobsen R. (2002) Tracer test with As(III) and As(V) at the Cape Cod Site. Geochim. Cosmochim. Acta 66, A356 (abstr).

Kornicker W.A. (1988) Interactions of divalent cations with pyrite and mackinawite in seawater and sodium-chloride solutions. Ph.D. thesis Texas A\&M Univ.

Kuhn A., Sigg L. (1993) Arsenic cycling in eutrophic Lake Greifen, Switzerland: influence of seasonal redox processes. Limnol. Oceanogr. 38, 1052-1059.

Lennie A.R. and Vaughan D.J. (1996) Spectroscopic studies of iron sulfide formation and phase relations at low temperatures. Min. Spectr., special publ. 5, 117-131.

Luther III G.W., Rickard D., Theberge S., Olroyd A. (1996) Determination of Metal (Bi)Sulfide Stability Constants of $\mathrm{Mn}^{2+}, \mathrm{Fe}^{2+}, \mathrm{Co}^{2+}, \mathrm{Ni}^{2+}, \mathrm{Cu}^{2+}$ and $\mathrm{Zn}^{2+}$ by Voltammetric Methods. Envir. Sci. Technol. 30, 671-679.

Mok W.M., Wai C.M. (1994) Mobilization of Arsenic in Contaminated River Waters. In: Arsenic in the environment, Part I: Cycling and characterization (ed. J.O. Nriagu), Wiley N.Y., pp 99-118.

Morse J.W., Arakaki T. (1993) Adsorption and coprecipitation of divalent metals with mackinawite (FeS). Geochim. Cosmochim. Acta 57, 3635-3640.

Morse J.W., Luther III, G.W. (1999) Chemical influences on trace metal-sulfide interactions in anoxic sediments. Geochim. Cosmochim. Acta 63, 3373-3378. 
Morse, J. W., Rickard, D. (2004) Chemical dynamics of sedimentary acid volatile sulfide. Envir. Sci. Technol. 38, 131A-136A.

Pierce M.L., Moore C.B. (1982) Adsorption of arsenite and arsenate on amorphous iron hydroxide. Water Res. 16, 1247-1253.

Pokrovski G., Gout R., Schott J., Zotov A., Harrichoury J-C. (1996) Thermodynamic properties and stoichiometry of $\mathrm{As}(\mathrm{III})$ hydroxide complexes at hydrothermal conditions. Geochim. Cosmochim. Acta 60, 737-749.

Rickard D., Luther III G.W. (1997) Kinetics of pyrite formation by the $\mathrm{H}_{2} \mathrm{~S}$ oxidation of iron (II) monosulfide in aqueous solutions between 25 and $125^{\circ} \mathrm{C}$ : The mechanism. Geochim. Cosmochim. Acta 61, 135-147.

Rochette E.A., Bostick B.C., Li G., Fendorf S. (2000) Kinetics of As(V) reduction by dissolved sulfide. Envir. Sci. Technol. 34, 4714-4720.

Smedley P.L., Kinniburgh D.G. (2002) A review of the source, behaviour and distribution of arsenic in natural waters. Appl. Geochem. 17, 517-568.

Spadini L., Bott M., Wehrli B., Manceau A. (2003). Analysis of the major Fe bearing phases in recent lake sediments by EXAFS spectroscopy. Aquat. Geochem. 9, 1-17.

Stumm W. (1991) Chemistry of the solid-water interface, processes at the mineral-water and particle-water interface in natural systems. Wiley \& Sons, NY, 428 p.

Suleimonov O.M., Seward T.M. (1997) A spectrophotometric study of hydrogen sulfide ionisation in aqueous solutions to $350^{\circ} \mathrm{C}$. Geochim. Cosmochim. Acta $\mathbf{6 1}, 5187-5198$.

Swedlund P.J., Webster J.G. (1999) Adsorption and polymerisation of silicic acid on ferrihydrite, and its effect on arsenic adsorption. Wat. Res. 33, 3413-3422.

Tossell J.A. (1997) Theoretical studies on arsenic oxide and hydroxide species in minerals and in aqueous solution. Geochim. Cosmochim. Acta 61, 1613-1623.

Tournassat C., Charlet L., Bosbach D., Manceau A. (2002) Arsenic(III) oxidation by birnessite and precipitation of manganese(II) arsenate. Envir. Sci. Technol. 36, 493500. 
Viollier E., Inglett P.W., Hunter K., Roychoudhury A.N., Van Cappellen P. (2000) The ferrozine method revisited: Fe(II)-Fe(III) determination in natural waters. Appl. Geochem. 15, 785-790.

Wagman D.D., Evans W.H., Parker V.B., Schumm R.H., Halow I., Bailey S.M., Churney K.I., Nuttall R.I. (1982) The NBS tables of chemical thermodynamic properties: selected values for inorganic and $\mathrm{C} 1$ and $\mathrm{C} 2$ organic substances in SI units. J. Phys. Chem. Ref. Data 11, suppl. 2, 392 p.

Waychunas G.A., Fuller C.C., Rea B.A., Davis J.A. (1996) Wide angle X-ray scattering (WAXS) study of "two-line" ferrihydrite structure: effect of arsenate sorption and counter ion variation and comparison with EXAFS results. Geochim. Cosmochim. Acta 60, 1765-1781.

Westall J., Zachary J.L., Morel F. (1976) MINEQL: A computer program for the calculation of chemical equilibrium composition of aqueous systems. Technical Note 18, Dept. of Civil Eng., M.I.T., Cambridge, Massachusetts.

Wharton M.J., Atkins B., Charnock J.M., Livens F.R., Pattrick R.A.D., Collison D. (2000) An X-ray absorption spectroscopy study of the coprecipitation of $\mathrm{Tc}$ and Re with mackinawite (FeS). Appl. Geochem. 15, 347-354.

Widler A.M., Seward T.M. (2002) The adsorption of gold(I) hydrosulphide complexes by iron sulphide surfaces. Geochim. Cosmochim. Acta 66, 383-402.

Wolthers M., Charlet L., van der Weijden C.H. (2003a) Arsenic sorption onto disordered mackinawite as a control on the mobility of arsenic in the ambient sulphidic environment. J. Phys. IV France 107, 1377-1380.

Wolthers M., van der Gaast S.J., Rickard D. (2003b) The structure of disordered mackinawite. Am. Mineral. 88, 2007-2015.

Wolthers M., Charlet L., van der Linde P.R., Rickard D., van der Weijden C.H. (accepted for publication in Geochim. Cosmochim. Acta) Surface chemistry of disordered mackinawite. 


\section{TABLES}

Table 1. Aqueous thermodynamic data used for equilibrium calculations $(I=0 \mathrm{M} ; T=298.15$ K). [1] MINEQL+ database (Westall et al., 1976); [2] Suleimonov and Seward, 1997; [3] calculated from Helz et al., 1995; [4] Eary, 1992; [5] Wolthers et al. (accepted); [6] Luther et al., 1996; [7] Davison et al., 1999.

\begin{tabular}{|c|c|c|}
\hline Hydrolysis reactions & $\log K$ & Reference \\
\hline $\mathrm{H}_{3} \mathrm{AsO}_{4}^{0} \leftrightarrow \mathrm{H}_{2} \mathrm{AsO}_{4}^{-}+\mathrm{H}^{+}$ & -2.25 & {$[1]$} \\
\hline $\mathrm{H}_{2} \mathrm{AsO}_{4}^{-} \leftrightarrow \mathrm{HAsO}_{4}^{2-}+\mathrm{H}^{+}$ & -6.83 & {$[1]$} \\
\hline $\mathrm{HAsO}_{4}^{2-} \leftrightarrow \mathrm{AsO}_{4}^{3-}+\mathrm{H}^{+}$ & -11.520 & {$[1]$} \\
\hline $\mathrm{H}_{3} \mathrm{AsO}_{3}^{0} \leftrightarrow \mathrm{H}_{2} \mathrm{AsO}_{3}^{-}+\mathrm{H}^{+}$ & -9.238 & {$[1]$} \\
\hline $\mathrm{H}_{2} \mathrm{AsO}_{3}^{-} \leftrightarrow \mathrm{HAsO}_{3}^{2-}+\mathrm{H}^{+}$ & -10.986 & {$[1]$} \\
\hline $\mathrm{HAsO}_{3}^{2-} \leftrightarrow \mathrm{AsO}_{3}^{3-}+\mathrm{H}^{+}$ & -13.470 & {$[1]$} \\
\hline $\mathrm{H}_{2} \mathrm{~S}(\mathrm{aq}) \leftrightarrow \mathrm{HS}^{-}+\mathrm{H}^{+}$ & -6.98 & {$[2]$} \\
\hline \multicolumn{3}{|l|}{ Complexation reactions } \\
\hline $\mathrm{H}_{3} \mathrm{AsO}_{3}^{0}+3 \mathrm{H}_{2} \mathrm{~S}(\mathrm{aq}) \leftrightarrow \mathrm{As}(\mathrm{SH})_{3}^{0}+3 \mathrm{H}_{2} \mathrm{O}$ & 0.81 & {$[3]$} \\
\hline \multicolumn{3}{|l|}{ Solubility products } \\
\hline $\mathrm{As}_{2} \mathrm{O}_{5}+3 \mathrm{H}_{2} \mathrm{O} \leftrightarrow 2 \mathrm{H}_{3} \mathrm{AsO}_{4}^{0}$ & 6.699 & {$[1]$} \\
\hline $\mathrm{As}_{2} \mathrm{O}_{3}+3 \mathrm{H}_{2} \mathrm{O} \leftrightarrow 2 \mathrm{H}_{3} \mathrm{AsO}_{3}^{0}$ & -2.804 & {$[1]$} \\
\hline $\mathrm{As}_{2} \mathrm{~S}_{3}(\mathrm{am})+6 \mathrm{H}_{2} \mathrm{O} \leftrightarrow 2 \mathrm{H}_{3} \mathrm{AsO}_{3}^{0}+3 \mathrm{H}_{2} \mathrm{~S}(\mathrm{aq})$ & -11.9 & {$[4]$} \\
\hline $\mathrm{As}_{2} \mathrm{~S}_{3}$ (orpiment) $+6 \mathrm{H}_{2} \mathrm{O} \leftrightarrow 2 \mathrm{H}_{3} \mathrm{AsO}_{3}^{0}+3 \mathrm{H}_{2} \mathrm{~S}(\mathrm{aq})$ & 40.03 & {$[1]$} \\
\hline $\mathrm{FeS}(\mathrm{s})+2 \mathrm{H}^{+} \leftrightarrow \mathrm{Fe}^{2+}+\mathrm{H}_{2} \mathrm{~S}(\mathrm{aq})$ & $4.87 \pm 0.27$ & {$[5]$} \\
\hline $\mathrm{FeS}(\mathrm{s})+\mathrm{H}^{+} \leftrightarrow \mathrm{FeSH}^{+}$ & $2.05 \pm 0.5$ & {$[6]$} \\
\hline $\mathrm{FeS}(\mathrm{s})+\mathrm{H}_{2} \mathrm{~S}(\mathrm{aq}) \leftrightarrow \mathrm{Fe}(\mathrm{SH})_{2}^{0}$ & $3.43 \pm 0.1$ & {$[7]$} \\
\hline
\end{tabular}


Table 2. Summary of site types, site capacities and protolysis constants proposed for $\mathrm{FeS}_{\mathrm{am}}$ (Wolthers et al., accepted), Freundlich equations and linear fits to the isotherms for $\mathrm{As}(\mathrm{V})$ and As(III) sorption.

\begin{tabular}{|c|c|c|}
\hline \multicolumn{2}{|l|}{ Site types } & Site capacities \\
\hline \multicolumn{2}{|l|}{$\equiv \mathrm{FeSH}^{0}$} & $1.2 \mathrm{mmol} \mathrm{g}^{-1} \mathrm{FeS}_{\mathrm{am}}$ \\
\hline \multicolumn{2}{|l|}{$\equiv \mathrm{Fe}_{3} \mathrm{SH}^{0}$} & $1.2 \mathrm{mmol} \mathrm{g}^{-1} \mathrm{FeS}_{\mathrm{am}}$ \\
\hline \multicolumn{2}{|c|}{ Surface protonation reactions } & $\log K$ \\
\hline$\equiv \mathrm{FeSH}^{0}+\mathrm{H}^{+}(\mathrm{aq})$ & $\leftrightarrow \quad \equiv \mathrm{FeSH}_{2}^{+}$ & $\log K_{\mathrm{st} 1}^{\mathrm{app}}=+8.0 \pm 0.1$ \\
\hline$\equiv \mathrm{FeSH}^{0} \quad \leftrightarrow$ & $\equiv \mathrm{FeS}^{-}+\mathrm{H}^{+}(\mathrm{aq})$ & $\log K_{\mathrm{st} 2}^{\mathrm{app}}=-6.5 \pm 0.1$ \\
\hline$\equiv \mathrm{Fe}_{3} \mathrm{SH}^{0}+\mathrm{H}^{+}(\mathrm{aq})$ & $\leftrightarrow \quad \equiv \mathrm{Fe}_{3} \mathrm{SH}_{2}^{+}$ & $\log K_{\mathrm{wk} 1}^{\mathrm{app}}=+7.85 \pm 0.05$ \\
\hline$\equiv \mathrm{Fe}_{3} \mathrm{SH}^{0} \quad \leftrightarrow$ & $\equiv \mathrm{Fe}^{3} \mathrm{~S}^{-}+\mathrm{H}^{+}(\mathrm{aq})$ & $\log K_{\mathrm{Wk} 2}^{\mathrm{app}}<-9.5$ \\
\hline \multicolumn{2}{|l|}{ Arsenic sorption } & Remarks \\
\hline \multicolumn{2}{|c|}{$[\mathrm{As}(\mathrm{V})]_{\mathrm{ads}}=0.021[\mathrm{As}(\mathrm{V})]_{\mathrm{aq}}^{0.90}$} & Freundlich equation \\
\hline \multicolumn{2}{|c|}{$\mathrm{K}_{\mathrm{d}},=\left([\operatorname{As}(\mathrm{V})]_{\mathrm{ads}}\right)\left([\operatorname{As}(\mathrm{V})]_{\mathrm{aq}}\right)^{-1} \approx 9 \mathrm{~L} \mathrm{~g}^{-1}$} & Linear fit to isotherm data \\
\hline \multicolumn{2}{|c|}{$[\mathrm{As}(\mathrm{III})]_{\mathrm{ads}}=0.026[\mathrm{As}(\mathrm{III})]_{\mathrm{aq}}^{0.98}$} & Freundlich equation \\
\hline \multicolumn{2}{|c|}{$\mathrm{K}_{\mathrm{d}},=\left([\mathrm{As}(\mathrm{III})]_{\mathrm{ads}}\right)\left([\operatorname{As}(\mathrm{III})]_{\mathrm{aq}}\right)^{-1} \approx 2 \mathrm{~L} \mathrm{~g}^{-1}$} & Linear fit to isotherm data \\
\hline
\end{tabular}




\section{FIGURE CAPTIONS}

Figure 1. (a) $\mathrm{As}(\mathrm{V})$ and (b) $\mathrm{As}(\mathrm{III})$ speciation at $0.05 \mathrm{M}$ ionic strength. Thermodynamic constants are taken from Table 1.

Figure 2. Fe concentrations in (a) the $\mathrm{As}(\mathrm{V})$ experiments, and (b) the As(III) experiments.

Figure 3. As(V) sorption data. (a) Experimental data showing the $\mathrm{pH}-\mathrm{dependence} \mathrm{of} \mathrm{sorption}$ at $[\mathrm{As}]_{\text {tot }} \approx 3 \times 10^{-5} \mathrm{M}$. Full line is model curve for linear sorption onto $\equiv \mathrm{FeSH}_{2}^{+}$surface species; (b) sorption isotherm at $\mathrm{pH} 7.5$, open and filled triangles are experimental data from duplicate experiments, the full line is the Freundlich equation (1) and the horizontal dashed line gives concentration of $\equiv \mathrm{FeSH}_{2}^{+}$at $\mathrm{pH} 7.5$ from Wolthers et al (accepted); (c) example of the first 30 minutes after $\mathrm{As}(\mathrm{V})$ addition (dashed line) in a duplicate experiment (open and filled triangles), $\mathrm{pH}$ varied from 7.8 to 7.4 and $[\mathrm{As}]_{\text {tot }} \approx 3 \times 10^{-5} \mathrm{M}$. In all cases, the suspension initially contained $0.044 \mathrm{~g} \mathrm{FeS} \mathrm{L}^{-1}$; the $[\mathrm{As}]_{\mathrm{ads}}$ data were corrected for solid dissolution (see text).

Figure 4. As(III) sorption data. (a) Experimental data showing the pH-dependence of sorption at $[\mathrm{As}]_{\mathrm{tot}} \approx 3 \times 10^{-5} \mathrm{M}$. (b) Sorption isotherm at $\mathrm{pH} 7.4$, experimental data (open and filled diamonds are duplicates), the Freundlich equation (2) (solid line) and the total concentration of mono- and three-coordinated surface sites $\left[\equiv \mathrm{Fe}_{\mathrm{X}} \mathrm{S}\right]_{\text {tot }}$ (horizontal dashed line) from Wolthers et al (accepted). (c) Example of the first 30 minutes after As(III) addition (dashed line) in a duplicate experiment (open and filled triangles), $\mathrm{pH}$ varied from 6.9 to 7.3 and

$[\mathrm{As}]_{\mathrm{tot}} \approx 3 \times 10^{-5} \mathrm{M}$. In all cases, the suspension initially contained $0.044 \mathrm{~g} \mathrm{FeS} \mathrm{L}^{-1}$; the $[\mathrm{As}]_{\mathrm{ads}}$ data were corrected for solid dissolution (see text). 


\section{FIGURES}
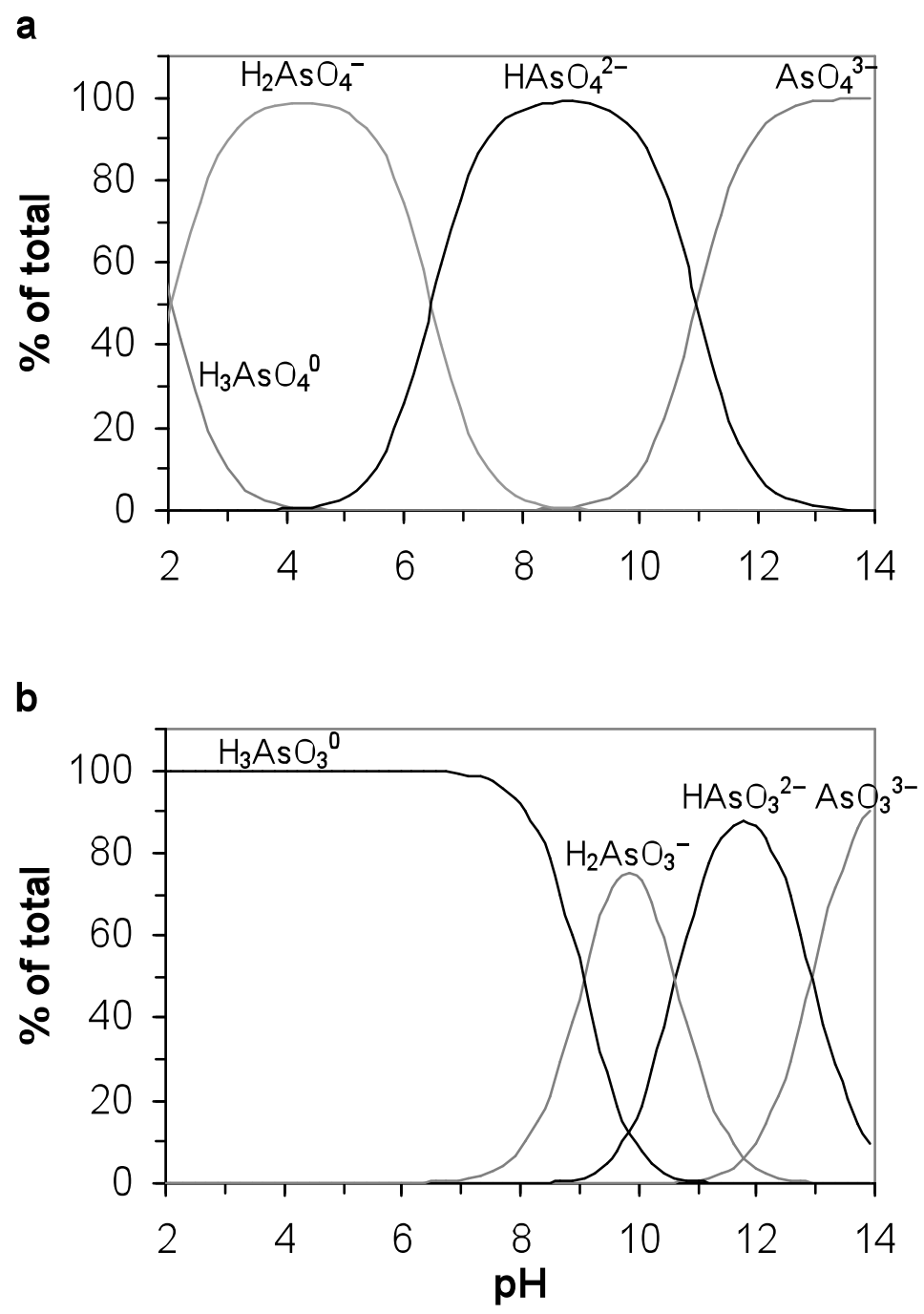

Figure 1. 

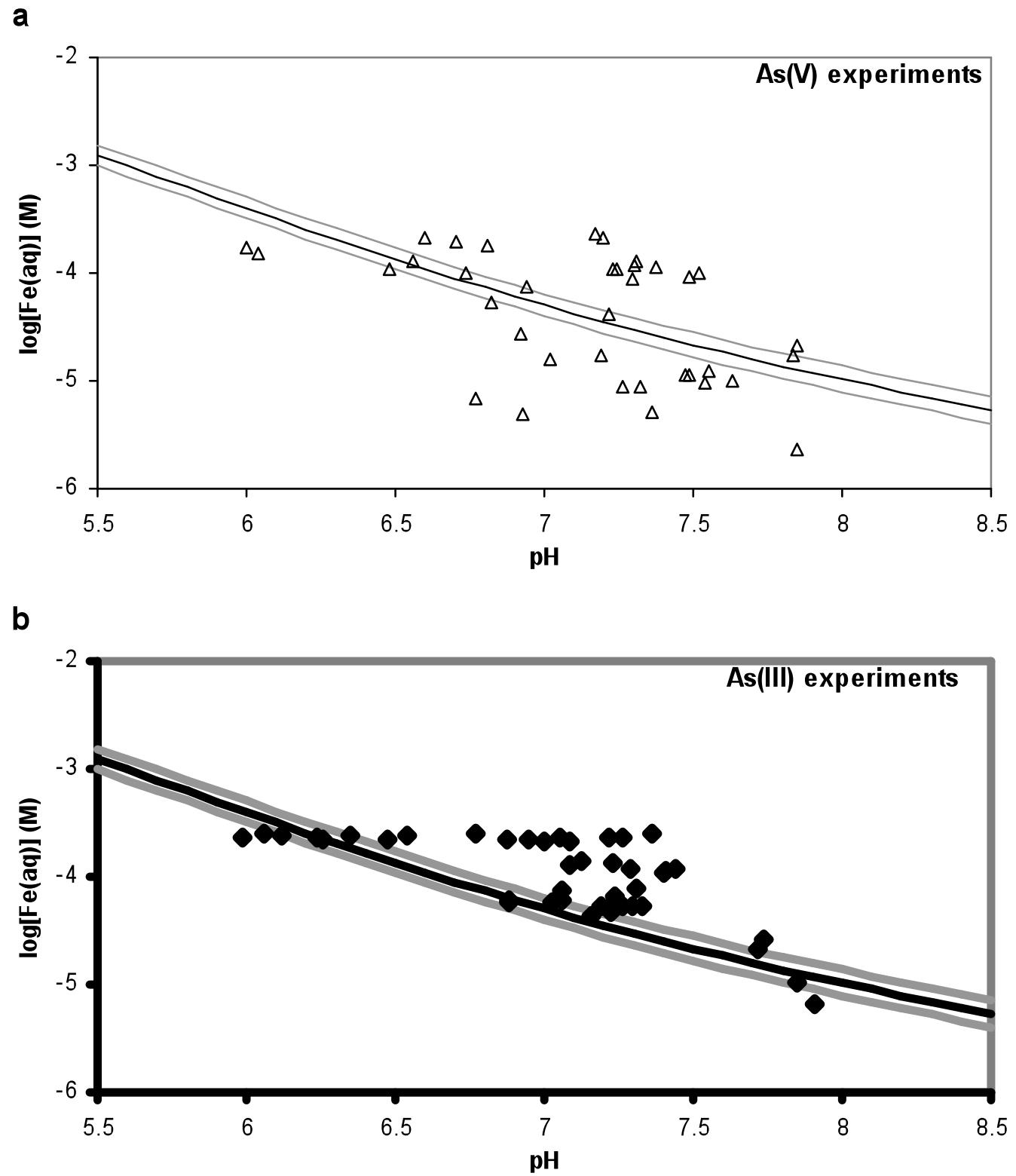

Figure 2. 

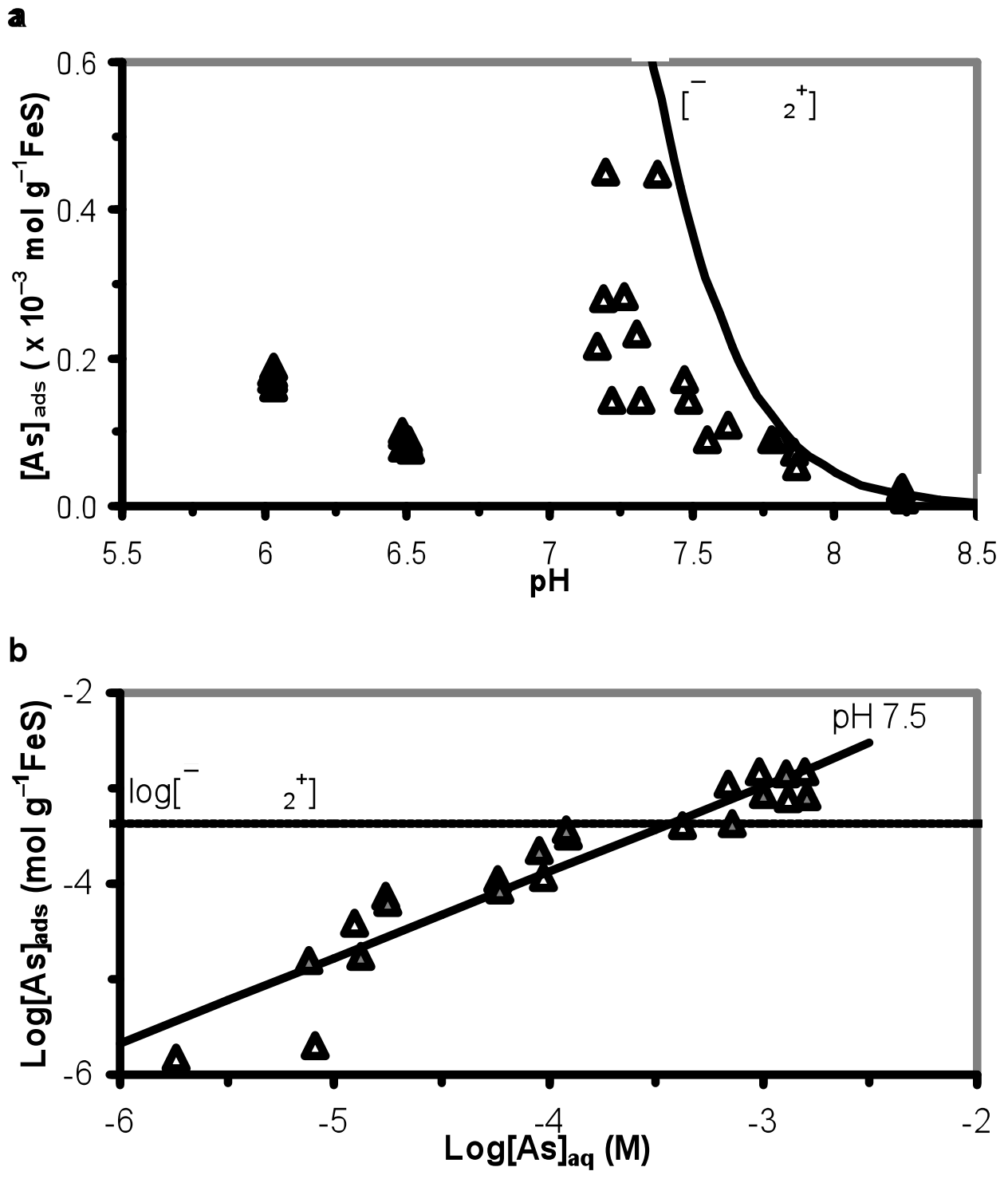

C

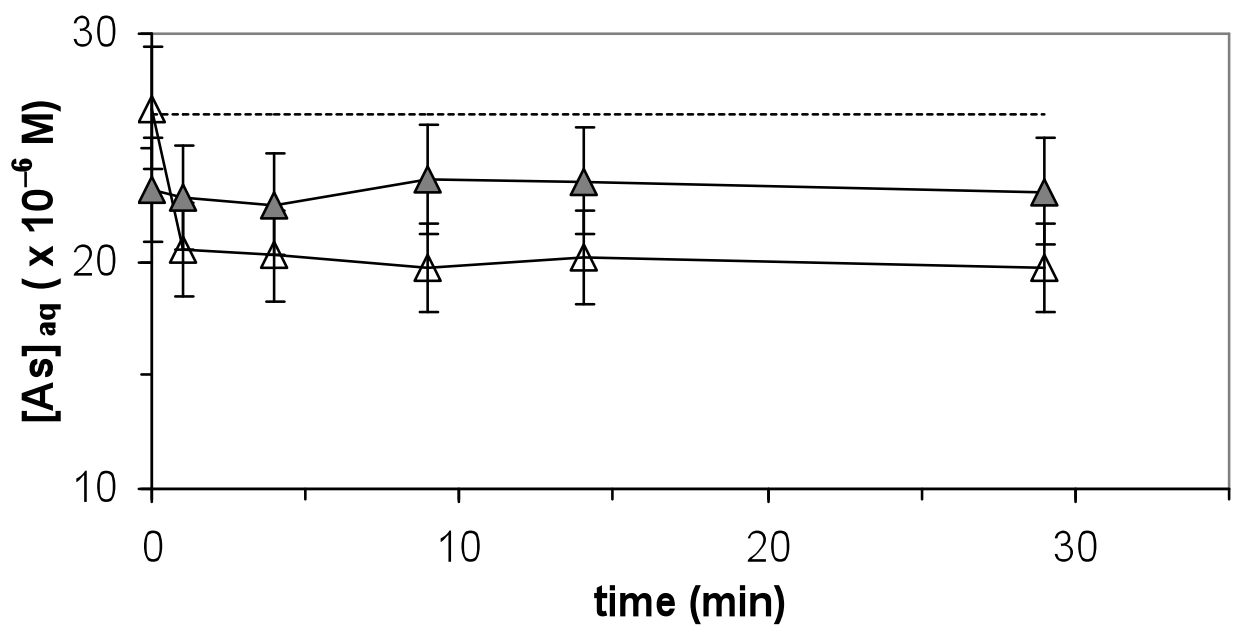

Figure 3. 
a
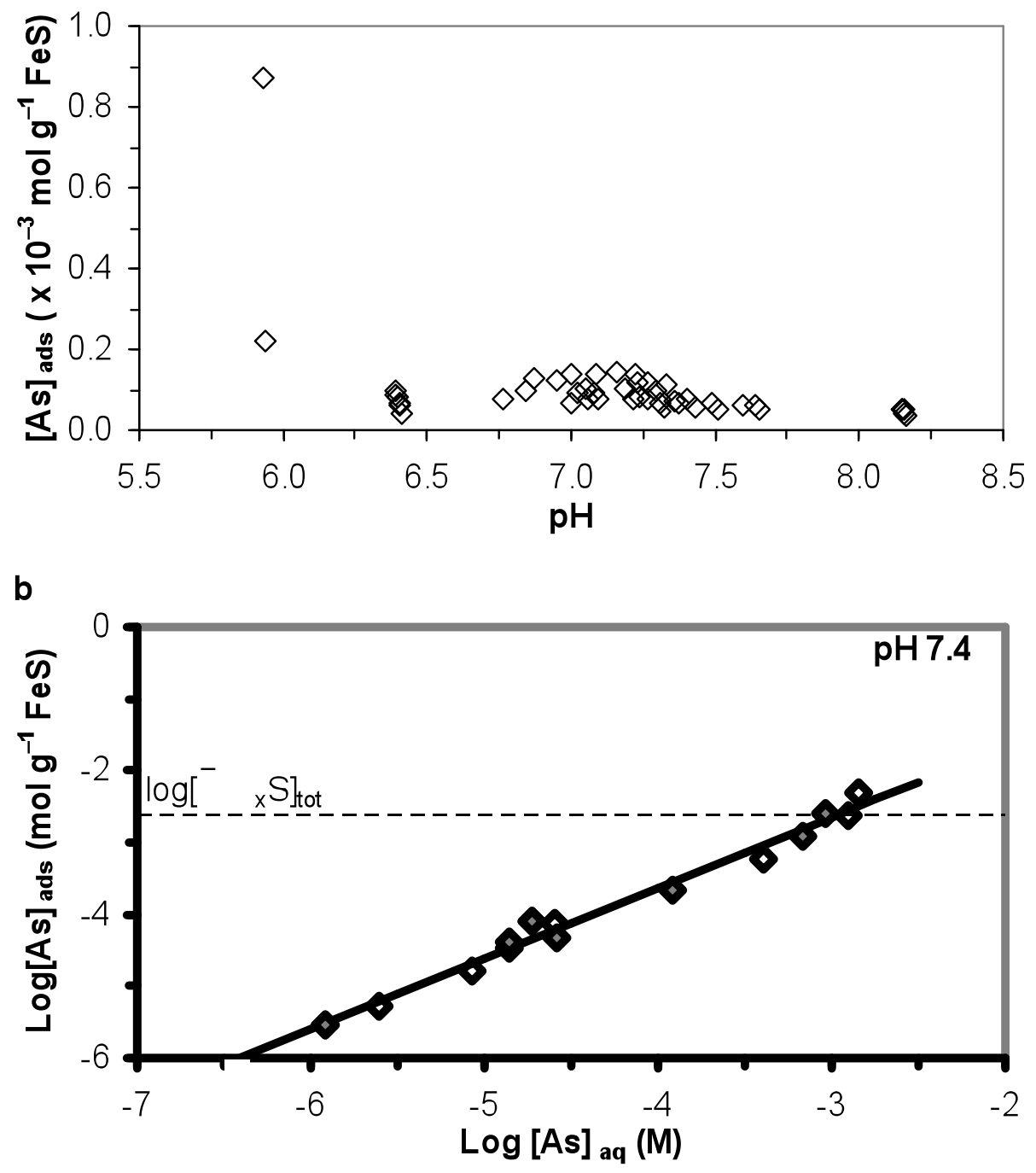

c

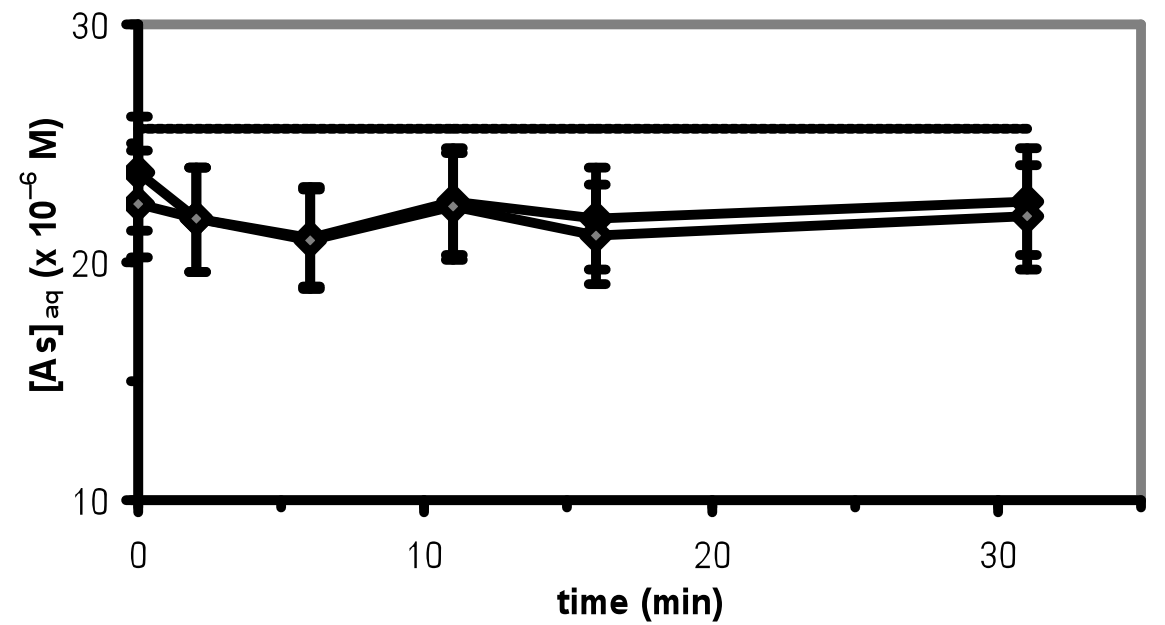

Figure 4. 